BBA 35675

\title{
STUDIES ON THE PARTIAL ISOLATION OF HUMAN RENIN
}

WERNER K. WALDHÄUSL*, CHARLES P. LUCAS, JEROME W. CONN, JOHN H. LUTZ** AND EDWIN L. COHEN

Department of Internal Medicine (Division of Endocrinology and Metabolism and the Metabolism Research Unit), The University of Michigan, Ann Arbor, Mich. (U.S.A.)

(Received May I3th, 1970)

SUMMARY

Studies on the partial isolation of human renin have been described. We have observed that:

I. Thorough disruption of the cell membranes by an all glass homogenizer increases the yield of enzyme eluted from renal tissue.

2. QAE-Sephadex and calcium gel cellulose chromatography are valuable tools for the purification of renin. Gradient elution is superior in ion exchange chromatography of human renin.

The properties of the final preparation obtained (Fraction 9) are: mol. wt. 42000 ; isoelectric point $\mathrm{pH} 5.25 ; A_{280 \mathrm{~m} \mu}: A_{\mathbf{2 6 0} \mathrm{m} \mu}=2 . \mathrm{I} ; \mathrm{pH}$ optimum for human substrate 5.5 ; hog substrate $7.5-8.5$; and tetradecapeptide renin substrate 5.5 . Specific activity 8.4 Goldblatt units per mg protein (by bioassay in the dog).

3. Evidence was obtained for the existence of considerable amounts of angiotensin I converting enzyme in human kidneys.

Problems concerning the standardisation of human renin have been discussed.

\section{INTRODUCTION}

Attempts to purify human renin have been made by several workers ${ }^{1-5}$. The specific activity reported varies from $0.5^{6}$ (ref. I) to 33 (ref. 4) units/mg of protein. The specific activities obtained are lower than those reported for renin extracted from tissues of other mammals ${ }^{6-9}$. At least part of the difference is due to the small amount of renin which is extractable from human kidneys as described by HAAs et al. ${ }^{\mathbf{1}}$.

The present study was undertaken with the objective of increasing the specific activity of human renin; and a comparative study of various extraction procedures

* Present address: I. Medizinische Universitätsklinik, Spitalgasse 23, A togo Wien, Austria.

** Present address: Gerontology Research Center, National Institute of Child Health and Human Development, National Institutes of Health, Baltimore City Hospitals, Baltimore, Md. 21224 , U.S.A. 
has been performed. Several chromatographic techniques, heretofore not employed for the isolation of human renin, have been evaluated. A procedure has been developed which retains $16 \%$ of the biologically active material of the crude extract. The properties of the obtained material were determined.

\section{EXPERIMENTAL PROCEDURES}

\section{Materials}

DEAE-cellulose, Type 20 was obtained from Schleicher and Schuell. Sephadex QAE-A5O, CM-C5O, G-I0o and G-200 superfine were purchased from Pharmacia Fine Chemicals, Uppsala, Sweden. Calcium phosphate gel $(30 \mathrm{mg} / \mathrm{ml})$ was a gift of Dr. Massey and was prepared by the method of SwINGLE AND TISELIUs ${ }^{11}$. Cellulose powder $\mathrm{CF} 2$ was obtained from Whatman; Ampholine $\mathrm{pH}$ 4-6 from LKB Instruments Inc., Rockville, Md. The following standard proteins were obtained from Mann Research Laboratories for the estimation of the molecular weight: human $\gamma$-globulin (mol. wt. I60 000), bovine serum albumin (mol. wt. 67 o0o), ovalbumin (mol. wt. 45 000), chymotrypsinogen (mol.wt. $25 \mathrm{ooo}$ ) and myoglobin (mol. wt. I7 800). Bovine serum albumin (Fraction V) was obtained from Armour, lysozyme from Worthington (Freehold, N.J.). A standard preparation of human renin (Lot I3, II-8-I965) was kindly provided by Drs. Haas and Goldblatt. A synthetic tetradecapeptide renin substrate (No. I07/7I; H-Asp-Arg-Val-Tyr-Ile-His-Pro-Phe-His-Leu-Leu-Val-Tyr-Ser$\mathrm{OH}$ ) was a gift of Dr. L. T. SkEGGS (see ref. I2). Hog renin plasma substrate was purchased from Pentex.

\section{Methods}

All procedures were carried out at $4^{\circ}$. Human kidneys were collected at autopsy and stored at $-20^{\circ}$. After removal of fat and connective tissue, the kidneys were homogenized by use of an electric meat grinder, a Waring Blender and by ro passes with an all glass homogenizer. The homogenate was centrifuged at $20000 \times g$ for 20 min (Sorvall Superspeed RC $2 B$, rotor GSA) and the supernatant saved. The amount of $\left(\mathrm{NH}_{4}\right)_{2} \mathrm{SO}_{4}$ used for various degrees of saturation was determined by use of a nomogram ${ }^{13}$.

Protein concentration was estimated either at $660 \mathrm{~m} \mu$ by the method of LowRY et al. ${ }^{14}$ or by measuring $A_{280 \mathrm{~m} \mu}$ in a Beckman DU spectrophotometer; recrystallized bovine serum albumin (Mann Research Laboratories) was used as a standard.

Pressure dialysis was performed as necessary with a Diaflo cell and UM Io membranes (diameter $62 \mathrm{~mm}$; Amicon, Lexington, Mass.) at 50-60 lb/inch ${ }^{2} \mathrm{~N}_{2}$.

Chromatographic procedures. Samples for chromatography were dialysed against three changes of the respective buffer for $24 \mathrm{~h}$.

Ion exchange chromatography: DEAE-cellulose was used as described by SkEGGS et al. ${ }^{15}$. QAE-A50 and CM-C 50 Sephadex were equilibrated with their respective buffer and used as described in the legends to Figs. I and 2. Gradient elution was according to PARR ${ }^{16}$.

Calcium phosphate gel was equilibrated with I mM Sørensen ${ }^{17}$ phosphate buffer ( $\mathrm{pH}$ 6.8) and mixed with cellulose, stirred and degassed as described by Mas$S E Y^{18}$. Consecutively a column of $4 \mathrm{~cm} \times 16 \mathrm{~cm}$ was packed under nitrogen at a pressure of $120 \mathrm{~mm} \mathrm{Hg}$. Specimens obtained from chromatography on QAE- or CM-Sephadex 
were applied to the column under the same pressure, which produced a flow rate of $3 \mathrm{ml} / \mathrm{min}$. Then the column was washed with $600 \mathrm{ml}$ of I $\mathrm{mM}$ phosphate buffer ( $\mathrm{pH} 6.8$ ) and eluted with the same buffer at (a) 20 , (b) 40 , (c) 80 and (d) I60 $\mathrm{mM}$ in $0.4 \mathrm{M} \mathrm{NaCl}$.

Gel filtration was carried out on columns, $2.5 \mathrm{~cm} \times 90 \mathrm{~cm}$ previously coated with Desicote (Beckman), of Sephadex G-Ioo and G-200 superfine. The columns were equilibrated and run with $0.075 \mathrm{M}$ Sørensen phosphate buffer (pH 7.5) containing o. I M KCl. The sample volume was $2 \mathrm{ml}$ or less, the amount of protein loaded ranged from 4 to $48 \mathrm{mg}$. Flow rate was $3 \mathrm{ml} / \mathrm{h}$. Usually fractions of $\mathrm{I} .5 \mathrm{ml}$ were collected.

Polyacrylamide gel electrophoresis was carried out with a Canalco Model 6 instrument at $\mathrm{pH}$ 8.6. Protein was stained with Coomassie blue obtained from Canalco.

Isoelectric focussing was performed with equipment from LKB Instruments Inc. (column size IIO $\mathrm{ml}$, LKB $8 \mathrm{I} 2 \mathrm{I}$ ) in a sucrose gradient according to the manufacturers directions. $2 \%$ ampholine $\mathrm{pH} \mathrm{4}^{-6}$ was used. Electrofocussing was achieved at $800 \mathrm{~V}$ and $2 \mathrm{~mA}$ after $72 \mathrm{~h}$.

Assay of renin activity. The renin activity was estimated by: (a) Bioassay in nephrectomized pentolinium treated rats as described by Conn et al. ${ }^{19}$ and Pickens et al. ${ }^{20}$. Infusion of $5 \%$ dextrose $(2-4 \mathrm{ml} / \mathrm{h})$ increased the sensitivity and extended the usefulness of the preparation. (b) Radioimmunoassay of angiotensin I and II as described by CoHEN et al. ${ }^{21}$. All samples were measured in triplicate. (c) Bioassay in the dog. (d) Double isotope derivative technique for the determination of angiotensin ${ }^{22}$.

Substrates and incubation procedures applied for the indirect determination of renin activity by bioassay in the rat and by radioimmunoassay were as follows:

(a) Bioassay. Human substrate was prepared according to HAAs et al. ${ }^{23}$ from pooled plasma of patients with low plasma renin activity. $300 \mu \mathrm{l}$ substrate were incubated at $37^{\circ}$ with Ioo $\mu \mathrm{l}$ of unknown sample in a Dubnoff shaker for the time given. If necessary, dilutions of the unknown sample were made in orders of magnitude with a solution of $10 \%$ human substrate in phosphate buffer $0.05 \mathrm{M}(\mathrm{pH} 6.9)$. The generation of angiotensin was stopped by heating in a boiling-water bath for Io min. Then I $\mathrm{ml}$ o.I5 M phosphate buffer ( $\mathrm{pH} 7.5$ ) was added and the denatured proteins removed by centrifugation. The supernatant was then assayed in the rat against a standard of angiotensin II (Ciba). The obtained values were corrected for a substrate blank and are expressed as ng angiotensin II generated per unit time.

Tetradecapeptide renin substrate was used as described by SkEGGS et al. ${ }^{\mathbf{2 4}}$. $0.5 \mathrm{nM}$ were incubated with human renin for $30 \mathrm{~min}$. Since tetradecapeptide renin substrate showed an intrinsic pressor effect, corrections for blank were made.

(b) Radioimmunossay. Hog plasma renin substrate ( $\mathrm{I} \mathrm{nM}$ ) was used according to Gould et al. ${ }^{25}$ and incubated for 10 min. A dilution series of standard renin was included into each run of determinations.

8-Hydroxyquinoline ( $5 \mathrm{mM})$, sodium thioglycolate $(50 \mathrm{mM})$ and EDTA $(25 \mathrm{mM})$ was added to human plasma substrate (acid-citrate-dextrose) to inhibit "angiotensinases". $500 \mu \mathrm{l}$ of this solution was incubated for Io min with roo $\mu$ l of unknown or standard solution. Diisopropylfluorophosphate $(4 \mu 1$, diluted 3:7 in isopropanol) was added prior to incubation. The generation of angiotensin I was stopped by immersing the reaction tubes into an ice bath.

"Angiotensinase activity" was measured by incubation of 2500 pg of angiotensin I or II with $5^{\circ} \mu \mathrm{l}$ of undiluted sample or blank in a final volume of $200 \mu \mathrm{l}$ of 
TABLE I

EFFECT OF VARIOUS EXTRACTION PROCEDURES ON THE YIELD OF HUMAN RENIN

\begin{tabular}{|c|c|c|c|c|c|c|}
\hline \multirow[t]{2}{*}{ Procedure } & \multirow[t]{2}{*}{$n$} & \multirow[t]{2}{*}{ Solvent } & \multirow[t]{2}{*}{$\begin{array}{l}\text { Tissue } \\
\text { (kg) }\end{array}$} & \multirow[t]{2}{*}{$\begin{array}{l}\text { Protein } \\
\text { (mg/kg) }\end{array}$} & \multicolumn{2}{|c|}{$\begin{array}{l}\text { Biological activity } \\
\text { (ng angiotensin II } \\
\text { per I6 h) }\end{array}$} \\
\hline & & & & & $\begin{array}{l}\text { per kg tissue } \\
\left(\times I O^{6}\right)\end{array}$ & $\begin{array}{l}\text { permg } \\
\text { protein } \\
\left(\times I 0^{3}\right)\end{array}$ \\
\hline \multicolumn{7}{|l|}{ Meat grinder, } \\
\hline Waring Blender & 3 & Distilled water & $1.2-20$ & $656-1200$ & $2.75-98$ & $3 \cdot 5-150$ \\
\hline + Ethanol & 4 & o.I $5 \mathrm{M} \mathrm{NaCl}$ & $0.6-4.5$ & $\mathrm{I}_{570-I_{4} 500}$ & $5.8-131$ & $7.0-30$ \\
\hline+ DEAE-cellulose & 4 & Distilled water & $0.8-1.0$ & II $74-3000$ & $17.4-56$ & $9 \cdot 9-56$ \\
\hline \multirow[t]{3}{*}{ Glass homogenizer } & I & o. I $5 \mathrm{M} \mathrm{NaCl}$ & 0.067 & I5 500 & 670 & 44 \\
\hline & $\mathbf{I}$ & $0.25 \mathrm{M}$ sucrose & 0.135 & 52250 & 1060 & 20 \\
\hline & I & + Ethanol & 0.100 & I 422 & 35 & 25 \\
\hline
\end{tabular}

o.I M Tris buffer ( $\mathrm{pH} 7.5$ ) containing Ioo $\mathrm{mg} / \mathrm{I}$ oo $\mathrm{ml} \mathrm{lysozyme} \mathrm{for} 60 \mathrm{~min}$. The reaction was stopped by heating in a boiling-water bath for Io min.

Specific activity (biological activity/mg protein) was expressed as: (I) ng angiotensin II per I6 h (rat bioassay), (2) units referring to a standard preparation of human renin, and (3) dog units.

Stability and $\mathrm{pH}$ optimum of human renin were tested at various $\mathrm{pH}$ in O.I $\mathrm{M}$ citric acid-o.I $\mathrm{M} \mathrm{Na}_{2} \mathrm{HPO}_{4}$ buffer. The $\mathrm{pH}$ above 8.0 was adjusted with o.I $\mathrm{M} \mathrm{NaOH}$.

RESULTS

Extraction

Table I shows the effect of various extraction procedures. The yield of human renin was compared after treatment of the crude extract with $0.8 \mathrm{M} \mathrm{NaCl}$ at $\mathrm{pH} 2.8$ and precipitation with $\left(\mathrm{NH}_{4}\right)_{2} \mathrm{SO}_{4}$. In order to precipitate most of the biologically active material available, a bracket of $\mathrm{I}_{5}-60 \%$ saturation, corresponding to $10-40 \%$ $(\mathrm{w} / \mathrm{v})\left(\mathrm{NH}_{4}\right)_{2} \mathrm{SO}_{4}$ was used. Similar yields of renin activity per $\mathrm{kg}$ tissue were obtained by simple homogenisation of the kidneys ${ }^{5}$ and by additional dehydration of the homogenate with ethyl alcohol ${ }^{26}$. The use of DEAE-cellulose as used by SKEGGs et al. ${ }^{15} \mathrm{did}$ not increase the yield of enzyme activity per $\mathrm{kg}$ tissue. However, if renal tissue previously minced by meat grinder and Waring Blender, and suspended $\mathrm{I}: 6$ in $0.25 \mathrm{M}$ sucrose or 0.I5 $\mathrm{M} \mathrm{NaCl}$, was homogenized in an all glass homogenizer the yield of biologically active material increased considerably. Additional use of ethyl alcohol at this stage caused a loss of renin activity. A further increase of extractable renin could be obtained by repeated freezing $\left(-70^{\circ}\right)$ and thawing of the homogenate.

\section{Ion exchange chromatography}

Fig. I shows the results of chromatography of the $\left(\mathrm{NH}_{4}\right)_{2} \mathrm{SO}_{4}$ fraction on QAEA5o Sephadex. The renin activity eluted with the second protein peak at pH 5.I-4.9. Samples loaded to this column with high biological activity were impossible to monitor by enzyme activity in the undiluted effluent. This effect was due to a high activity of angiotensinase for both angiotensin I and II. Dilution of the effluent $I: 5$ resulted in 


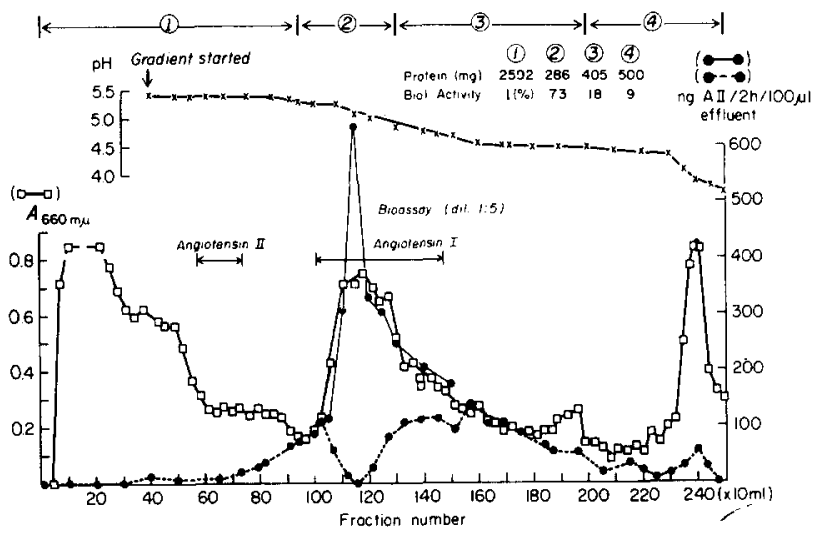

Fig. I. Chromatography of the $\left(\mathrm{NH}_{4}\right)_{2} \mathrm{SO}_{4}$ fraction on a column, $2.5 \mathrm{~cm} \times 60 \mathrm{~cm}$, of $Q A E-\mathrm{A}_{5} \mathrm{C}$ Sephadex. The column was equilibrated and run with $0.025 \mathrm{M}$ acetate buffer ( $\mathrm{pH} 5.35$ ) until the cationic proteins were eluted. Then a linear gradient was established using a cylindrical mixing chamber (100o $\mathrm{ml}$ ). Acetic acid $0.025 \mathrm{M}$ containing $0.015 \mathrm{M} \mathrm{NaCl}$, was added to the communicating reservoir. Renin activity was measured by bioassay (ng angiotensin II per 2 h per Ioo $\mu$ l effluent). Angiotensin I and II generated were measured by radioimmunoassay. The amount of protein eluted and the relative distribution of renin activity of the pooled fractions is indicated.

an increase of the generation of angiotensin. The determination of angiotensin I and II by the more sensitive radioimmunoassay revealed two separate peaks for angiotensin I and II as generated by the diluted effluent and human plasma substrate. The peak of angiotensin I coincided with the biologically detectable renin activity. Angiotensin II however was mainly generated by the preceding fractions which eluted shortly after the cationic proteins, but clearly before the second protein peak. The yield of the chromatographed fractions of human renin ranged from 73 to $95 \%$. The increase of specific activity was 4-13-6-fold.

CM-C50 Sephadex chromatography of the QAE-Sephadex fraction is shown on Fig. 2. Three protein peaks ( $\mathrm{pH} 4.9 ; \mathrm{pH} 5.35-5.6$; and $\mathrm{pH} 6.4$ with I $\mathrm{M} \mathrm{NaCl}$ ) were eluted. Human renin eluted with the descending slope of the second protein peak at

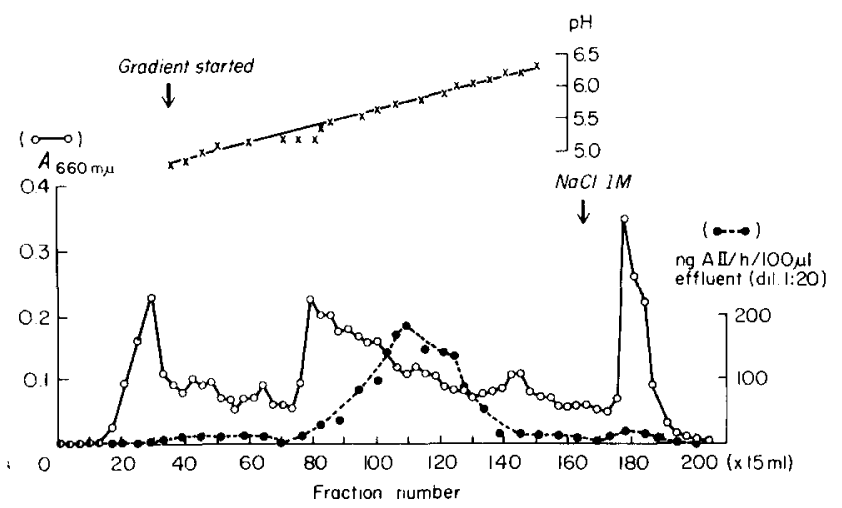

Fig. 2. Chromatography of the QAE-fraction on a column, $2.5 \mathrm{~cm} \times 60 \mathrm{~cm}$, of CM-C 50 Sephadex equilibrated with o.I M acetate buffer ( $\mathrm{pH}_{4}$.9). Elution was accomplished by (a) o. I M acetate buffer ( $\mathrm{pH} 4.9)$, (b) linear gradient elution with $0.2 \mathrm{M}$, acetate buffer ( $\mathrm{pH} 6.4$ ) and (c) I $\mathrm{M} \mathrm{NaC}$ in $0.2 \mathrm{M}$ acetate buffer ( $\mathrm{pH} 6.4)$. 


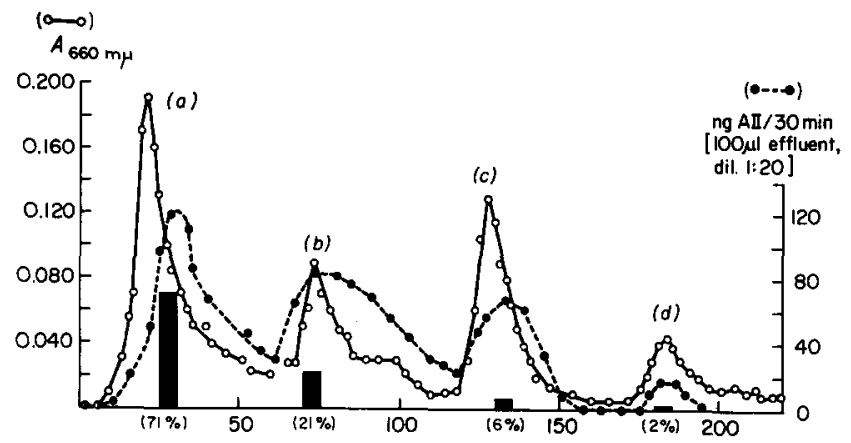

Fig. 3. Separation of human renin by calcium phosphate gel cellulose chromatography. Experimental details are given in Methods. The relative distribution of renin activity is shown by bars.

$\mathrm{pH} 5 \cdot 7-6.0$. The yield of this preparation was found to be between 50 and $106 \%$. The purification achieved was $3.2-8$-fold.

Calcium phosphate gel cellulose chromatography (Fig. 3)

This procedure was used for further purification of specimens obtained from chromatography on QAE- or CM-Sephadex. The bulk of the renin activity eluted with 20 and $40 \mathrm{mM}$ phosphate buffer in $0.4 \mathrm{M} \mathrm{NaCl}$. The distribution of renin activity between these two fractions was inconsistent. The optimal purification accomplished was 5.4-25-fold and depended on the amount of protein applied to the column. Smaller samples improved the purification, but decreased the yield slightly. Without the addition of $0.4 \mathrm{M} \mathrm{NaCl}$ renin eluted with $80 \mathrm{mM}$ phosphate buffer.

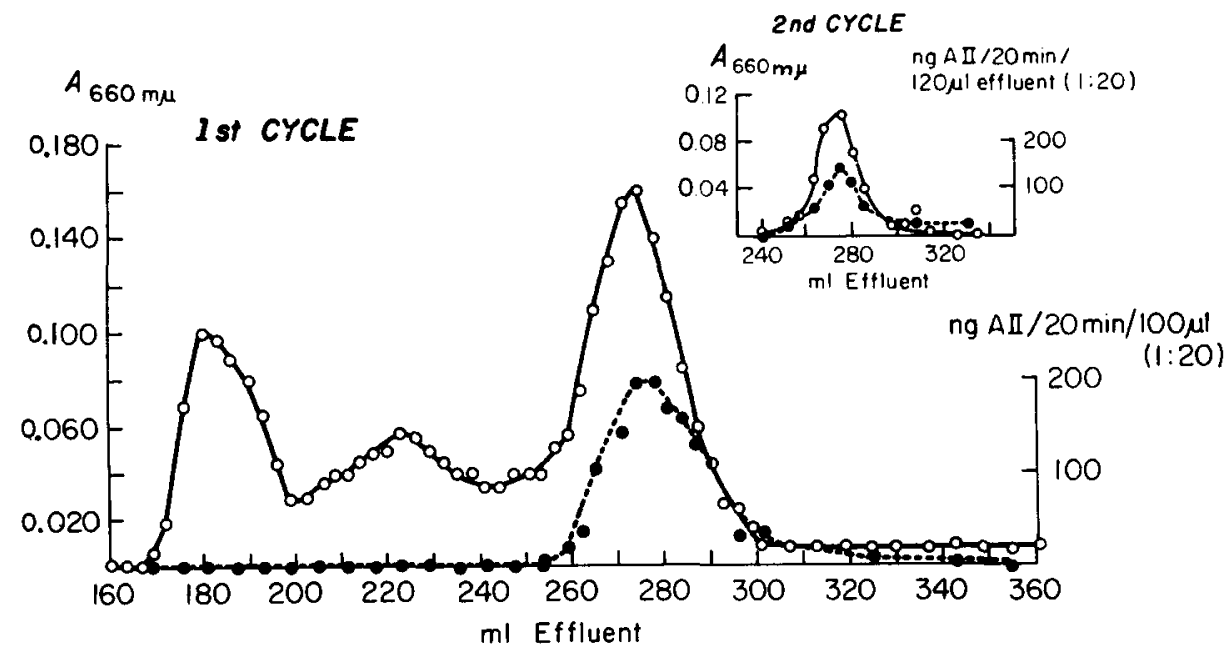

Fig. 4. Gel exclusion chromatography of human renin on Sephadex G-20o. Polyacrylamide gel chromatography showed three distinct bands for the biologically active protein peak (top). 
TABLE II

PREPARATION OF HUMAN RENIN FROM $5.75 \mathrm{~kg}$ OF RENAL TISSUE

The enzyme was extracted after glass homogenisation. The renin activity was estimated by radioimmunoassay for angiotensin $I$ and compared with standard renin. Calciumphosphate gel (procedures 6-8) has been eluted with phosphate buffer $(\mathrm{pH} \mathrm{6.8)}$ in $0.4 \mathrm{M} \mathrm{NaCl}$.

\begin{tabular}{|c|c|c|c|c|c|}
\hline Proceduve & $\begin{array}{l}\text { Protein } \\
(g)\end{array}$ & $\begin{array}{l}\text { Biological } \\
\text { activity } \\
\text { (units) }\end{array}$ & $\begin{array}{l}\text { Specific } \\
\text { activity } \\
\text { (units/mg) }\end{array}$ & $\begin{array}{l}\text { Yield } \\
(\%)\end{array}$ & $\begin{array}{l}\text { Purification } \\
\text { (-fold) }\end{array}$ \\
\hline I. Extraction & I 260 & 4200 & 0.0033 & "I00" & - \\
\hline 2. $\mathrm{pH} 2.8$ and $0.8 \mathrm{M} \mathrm{NaCl}$ & I 88 & 5000 & 0.026 & II9 & 7.8 \\
\hline 3. $\left(\mathrm{NH}_{4}\right)_{2} \mathrm{SO}_{4}$ & 43.6 & 3835 & 0.088 & 9 I & 26.6 \\
\hline 4. QAE-Sephadex & 2.9 & 3500 & 1.2 & 83 & 363 \\
\hline 5. CM-Sephadex & 0.8 & 3200 & $4 \cdot 0$ & 76 & I 2 I 2 \\
\hline 6. $20 \mathrm{mM}$ phosphate buffer & 0.144 & 1320 & 9. I & $3 \mathrm{I}$ & 2757 \\
\hline 7. $40 \mathrm{mM}$ phosphate buffer & 0.108 & I 500 & I 3.8 & 34 & 4184 \\
\hline 8. $80 \mathrm{mM}$ phosphate buffer & 0.222 & I 50 & 0.67 & $3 \cdot 4$ & - \\
\hline 9. Sephadex G-20o & 0.028 & 672 & $16-24$ & I 6 & $4^{848-7272}$ \\
\hline
\end{tabular}

Gel exclusion chromatography on Sephadex G-20o (Fig. 4)

An I.7-8.I-fold increase of specific activity was accomplished by gelfiltration on Sephadex G-200. This effect is inversely related to the specific activity of the applied sample. The recovery of the chromatographed protein solutions was $46-88 \% \cdot 30-63 \%$ of the biological activity were recovered after the first cycle. Rechromatography reduced the yield to $24 \%$ and also impaired the specific activity. Renin activity eluted at $260-300 \mathrm{ml}$ effluent. The peak of the enzyme activity was slightly shifted to the right of the protein even after rechromatography, suggesting the existence of various components of similar molecular weight.

\section{Protocol for the partial purification of human renin}

Table II summarizes the protein yields, the total units of renin activity recovered and the accumulated purification of the principal biologically active fractions obtained throughout the preparation. The overall yield of Fractions 6 and 7 was $65 \%$ of the extracted enzyme. Gel exclusion chromatography on Sephadex G-20o reduced the yield sharply to $16 \%$. Gel filtration of Fraction 7 gave higher specific activities (I6-24 units) than that of Fraction 6 (8-I2 units). The angiotensinase activity of Fraction 9 was negligible. This fraction showed three bands of very similar mobility on polyacrylamide disk electrophoresis (Fig. 4), and cross-reacted immunoelectrophoretically with two distinct lines with antirenin prepared previously ${ }^{5}$.

Properties of partially purified human renin (Table III)

(1) Gel filtration. The molecular weight of Fraction 9 was determined as described by ANDREWs ${ }^{27}$. As shown in Fig. 5 a linear relationship existed between the effluent values and the logarithm of the molecular weight of the proteins tested. From this graph the molecular weight of human renin was estimated to be 42000 .

(2) Isoelectric point. The isoelectric point of human renin was estimated by electrofocussing of $20-40 \mathrm{mg}$ of Fraction 6 (Table II). The peak of renin activity was eluted in three experiments at $\mathrm{pH}_{5.2-5.3}$ (Fig. 6). Gelfiltration of the electrofocussed preparation on Sephadex G Ioo was carried out to remove the low molecular ampho- 
TABLE III

PROPERTIES OF THE PREPARATION OF HUMAN RENIN

Molecular weight (gel filtration)

Isoelectric point

Optimal stability: (a)

(c)

$A_{280 \mathrm{~m} \mu}: A_{260 \mathrm{~m} \mu}$

$\mathrm{pH}$ optimum with (a) human substrate

(b) hog substrate

(c) tetradecapeptide

Specific activity (partially purified)

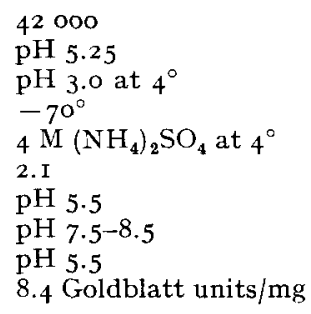

line. This procedure resulted in a steep loss of renin activity and reduced the specific activity to $0.5^{-1} .0 \mathrm{unit} / \mathrm{mg}$.

(3) Stability. Carrier free material ( I $^{-3} \mathrm{O}^{-3}$ unit) was stored in buffer of $\mathrm{pH} 3-9.5$ (see Methods) for 2 weeks. Maximal recovery of $92 \%$ was found at $\mathrm{pH} 3$, it declined with increasing $\mathrm{pH}$ to $49 \%$. Storage of human renin for 2 months was optimal (recovery $97^{-\mathrm{IO}} \%$ \%) in $4 \mathrm{M}\left(\mathrm{NH}_{4}\right)_{2} \mathrm{SO}_{4}$ at $4^{\circ}$ after addition of $\mathrm{Io} \mathrm{mg}$ bovine serum albumin per $\mathrm{ml}$, or at $-20^{\circ}$ and $-70^{\circ}$ without carrier protein. The recovery was impaired $\left(66 \%\right.$ ) by storage at $+4^{\circ}$ of both carrier free and carrier containing (Io $\mathrm{mg}$ bovine serum albumin per $\mathrm{ml}$ ) material. Lyophilisation of Fraction 9 (see Table II) at $-70^{\circ}$ caused a complete loss of biological activity as measured by bioassay.

(4) The ratio of $A_{280 \mathrm{~m} \mu}: A_{260 \mathrm{~m} \mu}$ of Fraction 9 was 2.I.

(5) Fig. 7 shows the effect of time on the hydrolysis of both human and hog substrate. The maximal generation of angiotensin by $I .7 \cdot \mathbf{I O}^{-\mathbf{3}} \mathrm{dog}$ unit (200 ng protein) was observed for human substrate after $60 \mathrm{~min}$. For hog plasma substrate ( $\mathrm{nM}$ ) the generation of angiotensin had not yet reached a plateau after $2 \mathrm{~h}$.

Fig. 8 demonstrates the effect of substrate concentration on the action of human renin. A clear substrate dependence of the velocity of hydrolysis is apparent for both human and hog substrate.

The effect of $\mathrm{pH}$ on the hydrolysis of various substrates by human renin is
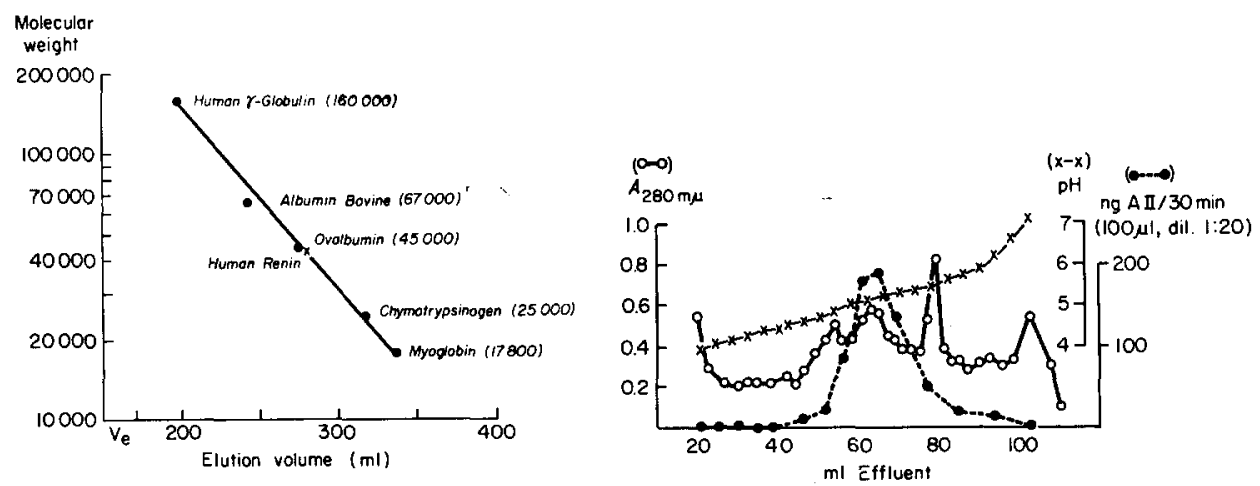

Fig. 5. Estimation of the molecular weight of human renin by gel-filtration on Sephadex G-20o. Experimental details are given in the text.

Fig. 6. Estimation of the isoelectric point of human renin ( $I=5.25$ ) by electrofocussing. 

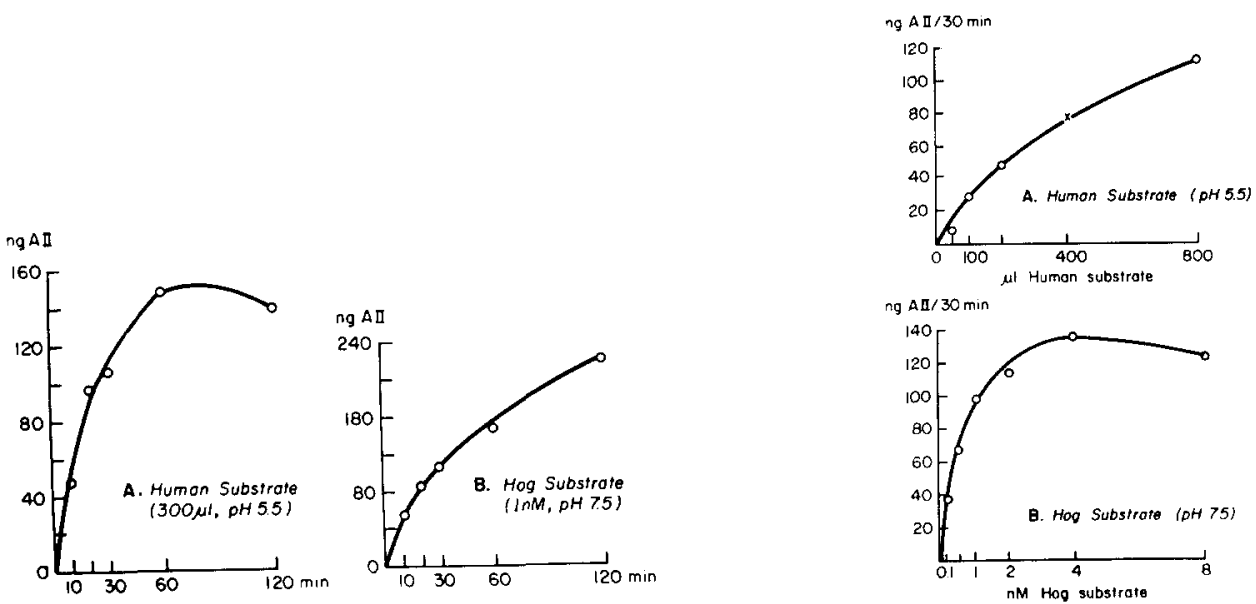

Fig. 7. Effect of time on the hydrolysis of human (A) and hog (B) plasma substrate by human renin (200 $\mathrm{ng} ; 8.4$ Goldblatt units/mg).

Fig. 8. Effect of substrate concentration (A, human; B, hog substrate) on the velocity of hydrolysis (human renin zoo ng; 8.4 Goldblatt units $/ \mathrm{mg}$ ).

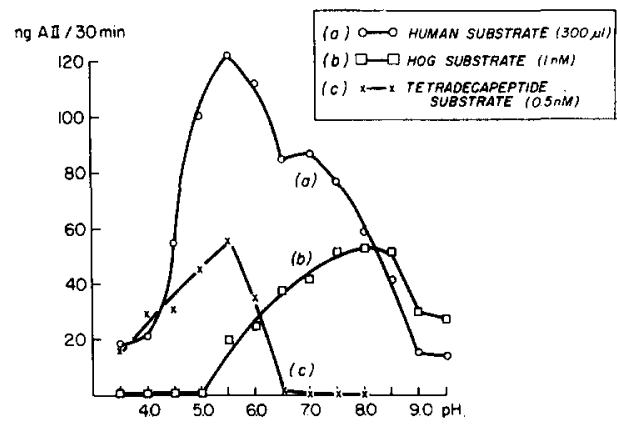

Fig. 9. Effect of $\mathrm{pH}$ on the hydrolysis of various substrates by human renin (200 ng; 8.4 Goldblatt units $/ \mathrm{mg}$ ).

demonstrated in Fig. 9. The $\mathrm{pH}$ optimum for the hydrolysis of human and tetradecapeptide renin substrate was found to be $\mathrm{pH}$ 5.5. Hog substrate was hydrolysed optimally at $\mathrm{pH} 7.5^{-8.5}$.

(6) Standardisation. The obtained preparations of human renin were evaluated vs. standard renin by various methods. The values for Fraction 9 were compared with some values reported in the literature (Table IV). Striking differences between the results of various procedures became apparent. The highest value of 37 units $/ \mathrm{mg}$ was obtained using the rat bioassay technique for the evaluation of the produced pressor material. The lowest specific activity (5.9 units $/ \mathrm{mg}$ ) was found with a double isotope derivative technique for the determination of angiotensin. Human substrate prepared by the method of HAAS et al. ${ }^{23}$ had the disadvantage that a very shallow slope ( $\triangle$ angiotensin/Arenin concentration) was obtained. No parallel dose response curves of standard renin and unknown could be obtained with this substrate using both bioassay and radioimmunoassay techniques. Approximately parallel dose response curves of standard renin and unknown samples (Fig. Io) and similar values of specific activity 
TABLE IV

SPECIFIC ACTIVITIES OF VARIOUS PREPARATIONS OF HUMAN RENIN

\begin{tabular}{|c|c|c|c|c|c|c|}
\hline \multirow[t]{3}{*}{ Reference } & \multicolumn{2}{|c|}{$\begin{array}{l}\text { Direct measurements of } \\
\text { renin activity }\end{array}$} & \multicolumn{4}{|c|}{$\begin{array}{l}\text { Indirect measurements of renin activity } \\
\text { (compared with Goldblatt's standard) }\end{array}$} \\
\hline & \multirow[t]{2}{*}{ Dog units } & \multirow[t]{2}{*}{ Cat units } & \multicolumn{2}{|c|}{ Bioassay } & \multicolumn{2}{|c|}{$\begin{array}{l}\text { Radioimmunoassay } \\
\text { (angiotensin I) }\end{array}$} \\
\hline & & & $\begin{array}{l}\text { Hog } \\
\text { sub- } \\
\text { strate }\end{array}$ & $\begin{array}{l}\text { Human } \\
\text { sub- } \\
\text { strate }\end{array}$ & $\begin{array}{l}\text { Hog } \\
\text { sub- } \\
\text { strate }\end{array}$ & $\begin{array}{l}\text { Human substrate } \\
\text { (S) or plasma } \\
\text { substrate }(P)\end{array}$ \\
\hline DEXTER et $a l .1$ & $\begin{array}{l}3.75-5.7^{\star} \\
0.56-0.86^{\star \star}\end{array}$ & $\begin{array}{l}\text { I } 5-23^{*} \\
2.25-3.45^{* *}\end{array}$ & - & - & - & - \\
\hline HAAs et al..$^{2}$ & 0.93 & - & - & - & - & - \\
\hline FukUChI AND CONN ${ }^{4}$ & - & - & - & 33 & - & - \\
\hline LuCAs et al. 5 & - & - & $\longrightarrow$ & $\underline{-5}$ & - & $5.0-12(\mathrm{~S})$ \\
\hline Fraction 9 & 8.4 & $5 \cdot 9^{\star \star \star}$ & $3 I-37$ & $24-27$ & I $5-2$ I.4 & I6 $-24(\mathrm{P})$ \\
\hline
\end{tabular}

${ }^{*}$ Per mg N.

** Per mg protein.

*** Double isotope derivative technique for the determination of angiotensin ${ }^{22}$.

(Fraction 9: 15-24 units/mg) were obtained when human and hog plasma renin substrate were used for the generation of angiotensin I as measured by radioimmunoassay. However, these curves were not yet stoichiometric. Linearity of response with added enzyme was only obtained by the double isotope derivative technique for the determination of angiotensin generated, and by the bioassay in the dog (Fraction 9; 8.4 Goldblatt units/mg).

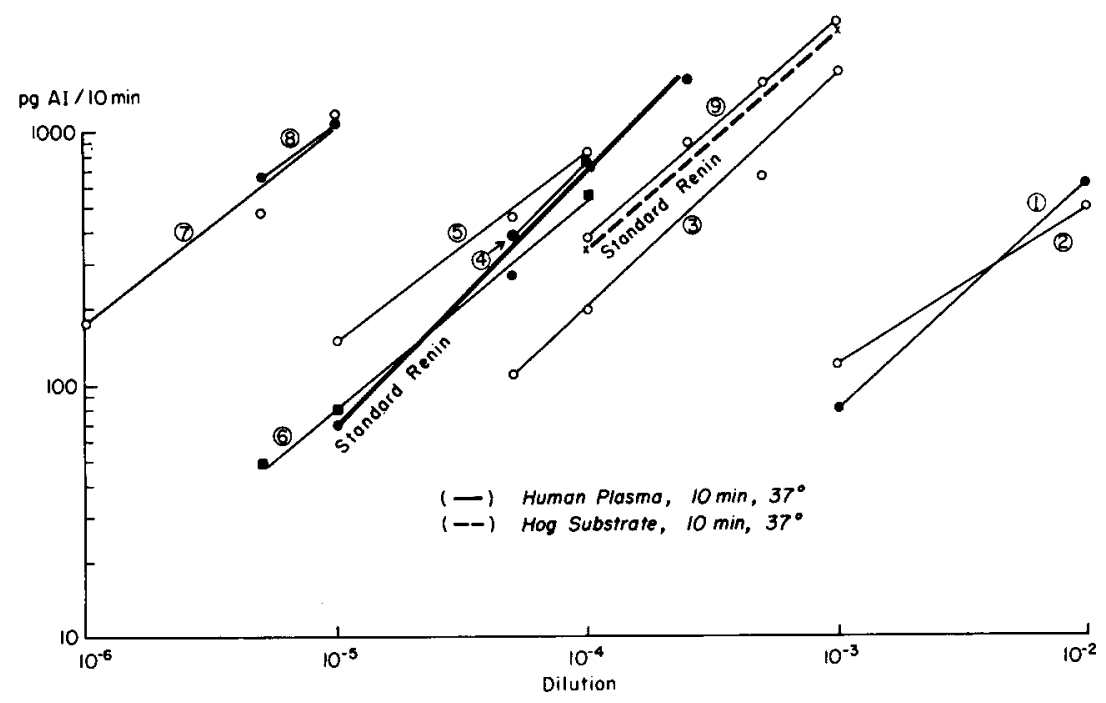

Fig. Io. Dose response curves for the standardisation of human renin. Dilution of standard renin vs. unknown Fractions I-9 (see also Table II). , human plasma substrate; - - - , hog plasma substrate. Angiotensin I generated was measured by radioimmunoassay. 


\section{DISCUSSION}

Thorough disruption of renal tissue by an all glass homogenizer improves the yield of renin activity extracted from human renal tissue. This effect is further enhanced by repeated freezing and thawing of the homogenized kidneys as also reported by OGiNo et al. ${ }^{28}$. By these means 730 units of renin activity per $\mathrm{kg}$ tissue were obtained for the crude extract, which compares favorably with the 137 units reported by others ${ }^{2}$.

The use of QAE-Sephadex and gradient elution from the ion exchange columns proved to be of additional advantage for the purification of renin. The simultaneous determination of angiotensin I and II as generated by the enzymes eluted from QAESephadex showed different maxima for both products (Fig. I). This pattern suggests the existence of considerable amounts of angiotensin converting enzyme in human kidneys and opens a new approach for further purification of this enzyme. A crude preparation of angiotensin I converting enzyme was obtained by SkEGGS et al. ${ }^{\mathbf{2 9}}$.

Chromatography of human renin on DEAE-cellulose (Fig. II) as on QAE- and CM-Sephadex (Figs. I and 2) gave no evidence for the existence of various types of human renin as has been observed by SkEGGS et al..$^{15}$ for hog renin. The elution of renin activity from calcium phosphate gel cellulose with both 20 and $40 \mathrm{mM}$ phosphate buffer in $0.4 \mathrm{M} \mathrm{NaCl}$ is possibly due to the small difference in ionic strength of the eluting buffer, but does not prove the existence of various types of human renin.

Human renin, Fraction 9 as obtained after gel filtration showed three bands of very similar mobility on polyacrylamide gel electrophoresis. It seems likely that one of the three protein components represents human globin; i.e. hemoglobin with the heme removed and a molecular weight of $4 \mathrm{I}$ 000-42 00o as described by RosSI-FANELLI et al. ${ }^{30,31}$. The estimated molecular weight confirms the value reported by WARREN AND DOLINSKY ${ }^{32}$ for crude human renin, which was prepared by the method of DEXTER ct al. ${ }^{1}$. The human enzyme appears in the lower range of the molecular weight estimated for hog renin by KEMP AND RUBIN ${ }^{33}$, and differs from the estimated molecular weight of a renin like substance reported previously ${ }^{34,35}$.

The observed $\mathrm{pH}$ optima of the obtained renin preparation with different substrates are the same as those described by GoulD et al. ${ }^{\mathbf{2 5}}$ for human renin. This

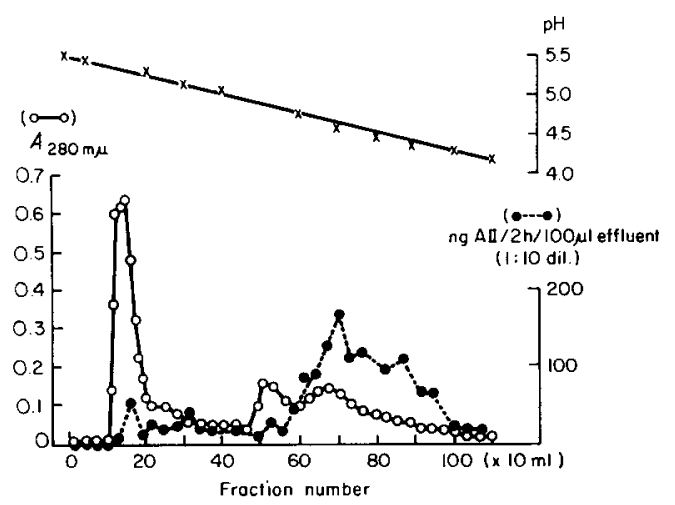

Fig. II. Chromatography of human renin on DEAE-cellulose. Column $2.5 \mathrm{~cm} \times 50 \mathrm{~cm}$. Gradient elution $\mathrm{pH} 5.5-4.0$ with $0.025 \mathrm{M}$ acetate buffer. 
provides clear differentiation between our preparation and pseudorenin as prepared by SKEGGs et al. ${ }^{24}$, which hydrolyses tetradecapeptide renin substrate optimally at $\mathrm{pH} 4.5$ and hog substrate at $\mathrm{pH} 5$.

The specific activity of Fraction 9 varied over a wide range depending on the procedure used (Table IV). When compared on the basis of the reported respective specific activities of various preparations the relationship was improved. Similarily, Boucher et al..$^{36}$ and PrCKens et al. ${ }^{20}$ had found considerable variations of angiotensin formation when a constant quantity of renin was added to different samples of plasma. This effect could be caused by varying amounts of "angiotensinase" in the substrate used.

The observed phenomena indicate that the values obtained represent only the apparent renin activity which is associated with the method applied. It appears that the result is influenced by a variety of circumstances such as the type and concentration of substrate(s), reaction products, activators and inhibitors of the enzyme system. The wide variation of the results suggests that various other compounds might be produced in addition to angiotensin I. Such substances could influence, either by pressor activity or by immunological cross reactivity with angiotensin I, both the results of the bioassay ("direct or indirect") and those of the radioimmunoassay for angiotensin I.

It seems important to emphasize that indirect measurements of renin activity using a standard preparation for comparison provide only a relative measure with which to follow the results of a purification procedure. It is therefore desirable to develop a direct assay for the determination of renin. In the meanwhile preparations should be tested "directly" in the dog before comparisons are made with other reported preparations.

\section{ACKNOWLEDGEMENTS}

This work has been supported in part by U.S. Public Health Service Grants TI AM 0500I and AM I0257, National Institute of Arthritis and Metabolic Diseases, National Institutes of Health.

We wish to express our deep appreciation to Drs. E. Haas and H. Goldblatt for determination of renin activity in the dog and for supplying us with standard renin. We are grateful to Dr. F. Medzihradsky for encouraging discussions and advice, to Dr. L. T. Skeggs for a gift of tetradecapeptide renin substrate and to Dr. R. I. Gregermann for the determination of renin activity by a double isotope derivative technique for angiotensin.

One of the authors (W.K.W.) is an International Postdoctoral Research Fellow of the National Institutes of Health.

\section{REFERENCES}

I L. Dexter, F. W. Haynes and W. C. Bridges, J. Clin. Invest., 24 (1945) 62.

2 E. Haas, H. Goldblatt and E. C. Gipson, Arch. Biochem. Biophys., I Io (I965) 564.

3 G. D. Lubash and W. S. Peart, Biochim. Biophys. Acta, I22 (I966) 289.

4 S. Fukuchi and J. W. Conn, J. Clin. Invest., 46 (I967) ro59, Abstract.

5 C. P. Lucas, S. Fukuchi, J. W. Conn, F. G. Berlinger, W. Waldhäusl and D. R. Rovner, J. Lab. Clin. Med., in the press.

6 E. Haas, H. Lamfrom and H. Goldblatt, Arch. Biochem. Biophys., 42 (1953) 368. 
7 F. C. Nairn, C. S. Chadwick and K. B. Fraser, Brit. J. Exptl. Pathol., 4 I (I960) 214.

8 H. H. Newsome, Biochim. Biophys. Acta, I85 (I969) 247.

9 E. Werle, I. Trautschold, K. H. Krammer und A. Schmal, Z. Physiol. Chem., 349 (I968) I 44 I.

io E. Haas, H. Lamfrom and H. Goldblatt, Arch. Biochem, Biophys., 48 (I954) 256.

i I S. M. Swingle and A. Tiselius, Biochem. $J$., 48 (I95I) I7I.

i 2 L. T. Skeggs, K. E. Lentz, J. R. Kahn and N. P. Shumway, J. Exptl. Med., io8 (1958) 283.

I 3 M. Dixon, Biochem. J., 54 (I953) 457.

i 4 O. H. Lowry, N. J. Rosebrough, A. L. Farr and R. J. Randall, J. Biol. Chem., I93 (I95I) 265.

is L. T. Skeggs, K. E. Lentz, J. R. Kahn and H. Hochstrasser, Suppl. II to Circulation Res., 20 and 2 I (I967) II-9I.

I6 C. W. PARR, Biochem. J., 56 (1954) XXVII.

I7 S. P. L. Sørensen, Biochem. Z., 22 (I909) 352. L.c. Documenta Geigy, (I960) 277.

I 8 V. Massey, Biochim. Biophys. Acta, 37 (1960) 3 Io.

ig J. W. Conn, E. L. Cohen and D. R. Rovner, J. Am. Med. Assoc., igo (I964) 2 I3.

20 P. T. Pickens, F. M. Bumpus, A. M. Lloyd, R. R. Smeby and I. H. Page, Circulation Res., I7 (I965) 438 .

2 I E. L. Cohen AND J. W. Conn, in preparation.

22 R. I. Gregerman and M. A. Kowatsch, Biochem, Med., 3 (I969) I 3.

23 E. Haas, H. Goldblatt, F. C. Gipson and L. V. Lewis, Circulation Res., ig (1966) 739.

24 L. T. Skeggs, K. E. Lentz, J. R. Kahn, F. E. Dorer and M. Levine, Circulation Res., 25 (I969) 45 I.

25 A. Gould, L. T. Skeggs and J. R. Kahn, Lab. Invest., I5 (1966) I802.

26 W. S. Peart, A. M. Lloyd, G. N. Thatcher, A. F. Lever, N. Payne and N. Stone, Biochem. J., 99 (I 966$) 708$

27 P. ANDREWS, Biochem. J., 9I (I964) 222.

28 K. Ogino, M. Matsunaga, N. Saito, J. Kira and M. Takayasu, Japan. Circulation J., 3I (I967) I.

29 L. T. Skeggs, J. R. Kahn and W. P. Shumway, J. Exptl. Med., io3 (1956) 295.

3o A. Rossi-Fanelil, E. Antonini and A. Caputo, J. Biol. Chem., 234 (1959) 2906.

3 I A. Rossi-Fanelli, E. Antonini and A. Caputo, Biochim. Biophys. Acta, 28 (1958) 22 I.

32 B. Warren and M. Dolinsky, Proc. Soc. Exptl, Biol. Med., I23 (Ig66) 9 I I.

33 E. Kemp and I. Rubin, Acta Chem. Scand., i 8 (I964) 2403.

34 T. KENNER AND W. WALDHÄUSL, Nature, 204 (1964) $58 \mathrm{I}$.

35 M. Peterlik and W. Waldhäusl, Nature, $214(1967) 279$.

36 R. Boucher, R. Veyrat, J. De Champlain and J. Genest, Can. Med. Assoc.J., 90 (1964) I94.

Biochim. Biophys. Acta, 22 I (1970) 536-548 